\title{
СОЦІАЛЬНО-ПСИХОЛОГІЧНИЙ СУПРОВІД СТУДЕНТА У ПЕРІОД АДАПТАЦЇ̈ ДО НАВЧАННЯ У ВУЗІ
}

Професійний розвиток особистості майбутнього фахівия починається у вищому навчальному закладі, де формуються його професійно значущі якості, інтереси, потреби, творчі здібності, зростає загальний рівень культури.

У статті наведено теоретичний аналіз існуючих у сучасній науці підходів до вивчення проблеми адаптації студентів до навчання у вищих навчальних закладах. Розкрито основні проблеми адаптації студентів до навчання у ВНЗ. Представлено результати анкетування студентів-першокурсників та надано рекомендації щцодо вдосконалення прочесу адаптації студентів-першокурсників до навчання у ВНЗ. Запропоновано програму соціально-психологічного супроводу студентів нового набору в адаптаційний період.

Ключові слова: адаптація, адаптащчійний процес, соиіалізація., студентпершокурсник, форми адаптащіï, сочіально-психологічний супровід.

Профессиональное развитие личности будущего специалиста начинается в высшем учебном заведении, где формируются его профессионально значимые качества, интересы, потребности, способности, растет общий уровень культуры. $B$ статье приведен теоретический анализ существующих в современной науке подходов к изучению проблемы адаптаџии студентов к обучению в высших учебных заведениях. Раскрыты основные проблемы адаптации студентов $к$ обучению в вузе. Представлены результать анкетирования студентов-первокурсников и даны рекомендащии по совершенствованию прочесса адаптации студентов-первокурсников к обучению в вузе. Предложена программа сочиально-психологического сопровождения студентов нового набора в адаптационный период.

Ключевые слова: адаптации, адаптационный проиесс, социилизация, формьь адаптации, социально-психологическое сопровождение.

Ми вступаємо в різні періоди нашого життя так, як немовлята, не маючи за плечима ніякого досвіду, хоч би скільки нам було років.

(Ф. Ларошфуко)

Постановка проблеми. Сучасна реформа освіти актуалізує питання підготовки відповідального, ініціативного, вмотивованого, висококваліфікованого фахівця, здатного до ефективної роботи зі спеціальності на рівні світових стандартів, готового до постійного професійного удосконалення.

Професійний розвиток особистості майбутнього фахівця починається у вищому навчальному закладі, де формуються його професійно значущі якості, інтереси, потреби, творчі здібності, зростає загальний рівень культури. Оскільки студент перебуває у складній ситуації знайомства 3 новими формами діяльності, спілкування, дозвілля, співвідносить власні сподівання з реальністю, формується його ставлення до навчальної діяльності, тому процес адаптації майбутніх фахівців до умов вищого навчального закладу $є$ важливим етапом професійної підготовки.

Формулювання цілей статті. 3 цією метою були поставлені завдання дослідити основні теоретико-методологічні принципи і підходи до проблеми соціально-психологічної адаптації студентів ВНЗ; вивчити структурні компоненти і функціональні механізми адаптаційного процесу до умов життєдіяльності ВНЗ; розробити рекомендації по створенню програми соціально-психологічного супроводу спрямованої на забезпечення успішної адаптації студентів до навчання у ВНЗ.

Аналіз останніх досліджень і публікацій. Аналіз наукової літератури вказує на те, що питання адаптації студентів до умов навчання у вищому навчальному закладі займає одне 
3 провідних місць у дослідженнях щодо проблем формування особистості майбутнього фахівця. Питанням адаптації присвячені наукові дослідження О. Безпалько, Н. Заверико, Л. Коваль, Г. Лактіонової, А. Мудрик. Труднощі початкового етапу навчання і чинники, що впливають на процес адаптації у своїх наукових працях розкривали О. Прудська, А. Андрєєва, С. Гапонова, Ю. Бохонкова. Проблемі адаптації студентів до навчання в умовах вищого навчального закладу приділяється багато уваги такими науковцями як Т. Алмазова, Ю. Бохонкова, Н. Герасімова, Н. Жигайло, О. Кочерук. Адаптацію як необхідну умову соціалізації людини розглядають М. Лукашевич, А. Мудрик, С. Пальчевський. В. П. Каземіренко та інші науковці розробили програму дослідження соціальнопсихологічних чинників адаптації молоді до навчання у ВНЗ та майбутньої професії. Такі вчені, як Л. Красовська, М. Прищак, Л. Гармаш, О. Маріна, О. Стягунова роблять акцент на важливості адаптації першокурсників до навчання, підкреслюючи те, що успішність перебігу процесу адаптації є запорукою сприятливого розвитку у певному соціумі.

Виклад основного матеріалу дослідження. У Великому психологічному словнику під редакцією Б. Р. Мещерякова, В. П. Зінченко вказано, що адаптація (adaptation) (від лат. adaptatio - пристосування) - процес і результат ефективної взаємодії особистості iз середовищем, в результаті якого встановлюється відповідність між загальним рівнем найбільш актуальних на даний момент потреб особистості і наявним (перспективним) рівнем задоволення даних потреб, що визначає безупинний розвиток особистості [7, с. 16]. Період адаптації першокурсника пов'язаний із руйнуванням раніше сформованих стереотипів, що може породжувати труднощі як у навчанні (порівняно зі школою низька успішність), так і в спілкуванні. Адаптаційний період у різних студентів відбувається по-різному, залежно від їхніх індивідуально-психологічних особливостей, рівня готовності до навчання у вищій школі. Як зазначив А. А. Налчаджян, ліміти його адаптивних можливостей не безмежні. I для того, щоб досягти стану адаптованості, необхідно вибирати певний вид поведінки і певні внутрішні умови (розвиненість адаптивних механізмів, певний загальний рівень психічної зрілості тощо). Адаптованість як результат процесу адаптації студентів до навчання у вищому навчальному закладі може досягатися з різною динамікою, мати різний вихідний вид $[5$, c.28].

Досліджуючи питання адаптації студентів-першокурсників у вищому навчальному закладі можна зазначити, що адаптаційний період, який починається з перших днів навчання $\epsilon$ дуже важливим етапом, адже саме в цей час відбувається «активне, творче пристосування студентів нового прийому до умов вищої школи, в процесі якого в студентів формуються оптимальні взаємини, покликання до обраної професії, раціональний колективний режим праці та побуту» [4, с.15]. Усі ці труднощі різні за своїм походженням. Деякі з них $\epsilon$ об'єктивно неминучі, інші носять суб'єктивний характер і пов'язані зі слабкою підготовкою, прогалинами виховання у родині та школі.

Критеріями успішної адаптації студентів до умов вищого навчального закладу (за Е.Ф.Зеєром) є адаптація до навчально-пізнавального середовища, особистісне самовизначення і вироблення нового стилю життєдіяльності. Т. Цепеліна, О. О. Стягунова в свою чергу, виділяють такі критерії успішної адаптації студентів першого курсу до навчання в умовах ВН3 [2, с. 21]:

- пізнавальний (дидактичний) - відповідність навчальних і професійних інтересів; стійка потреба у знаннях із фахових дисциплін; наявність певних знань із майбутньої професійної діяльності; порівняння попереднього досвіду спілкування 3 учасниками групи, функціонування у попередньому соціумі із теперішнім, із наявною системою ціннісних орієнтацій і установок;

- емоційний - стійке позитивне та зацікавлене ставлення до обраного фаху; позитивна оцінка нової групи, прийняття групових норм, в результаті чого відбувається поступова ідентифікація індивіда з цією групою;

діяльнісний (чи практичний) - стійка потреба в діяльності, максимально наближеної до майбутньої професії; активна позиція при опануванні професійно значущих дисциплін; прийняття активної участі в житті студентського колективу; 
- $\quad$ вольовий - упевненість як у подоланні труднощів, пов'язаних з оволодінням професійною діяльністю, так i y вирішенні проблемних ситуацій на соціальному i побутовому рівнях.

Науковці виділяють 3 сфери адаптації студентів: навчальний процес і навчальне навантаження; новий колектив (як студентський, так і педагогічний); інші умови життя (самостійна організація навчальної діяльності, побуту та вільного часу) [7-с.26].

Тому, процес адаптації студентів у вищому навчальному закладі можна розглядати як комплексну проблему, адже їм доводиться пристосовуватись до зміни відпочинку і праці, до нової системи навчання та входження в новий колектив. Саме тому, постає необхідність у створенні відповідної програми соціально-психологічного супроводу студента у період адаптації до навчання у вузі.

\section{Програма передбачає:}

- соціально-психологічний супровід, спрямований на успішну соціалізацію студентів-першокурсників в умовах вищого навчального закладу;

- індивідуальну роботу із студентами, відповідно до їхніх потреб та проблем;

- групові заходи, розраховані на створення позитивного емоційного комфорту в академічній групі нового набору;

- проведення необхідної просвітницької, консультативної, діагностичної та корекційно-розвивальної роботи з усіма учасниками навчально-виховного процесу;

- методичну роботу, зокрема, підготовку методичних рекомендацій батьківському та педагогічному колективам, укладання різноманітних пам'яток, бюлетенів, посібників для студентів, розробку тренінгових занять, годин спілкування, інших заходів тощо.

Програма адаптації може формуватися за такими напрямками: інформаційноорганізаційний; діагностичний; консультативно-просвітницький; корекційно-розвивальний; підсумково-оцінювальний.

Інформаційно-організаційна робота. На цьому етапі доцільно вивчити особові справи, зустрітись 3 керівниками академічних груп, познайомитись зі студентами нового набору, оформити стенд 3 порадами щодо успішної адаптації до навчання у закладі.

Діагностичні дослідження дають змогу констатувати, що психодіагностика адаптаційних можливостей студентів першого року навчання дуже важлива, тому, що дезадаптації може позначитися погіршенням роботи пізнавальної сфери, зміни в емоційнопочуттєвій сфері [3]. Обов'язковим на цьому етапі $є$ дослідження соціальної адаптованості за П. Кузнецовим. Соціальна адаптація - активний процес пристосування людини до нового соціального середовища. За результатами методики П. Кузнецова (м. Сарни, педагогічний коледж, вересень-жовтень 2017 року) більша частина студентів нового набору має середній рівень соціальної адаптованості. Цей показник коливається від 36\% до 84\% по групам.

Варто зазначити, що не менш важливим є вивчення особистісних характеристик студента. Для цього можна використати методику визначення реактивної (ситуативної) та особистісної тривожності за Шкалою Ч.Д. Спілбергера - Ю. Л. Ханіна. Так, за показниками у студентів було виявлено низького рівня ситуативної тривожності лише $6 \%$, середнього рівня 57\%, високої ситуативної тривожності 37\%. Особистісної тривожності низького рівня у студентів виявлено 4\%, середнього рівня виявлено $37 \%$, високого рівня 59\%. Ці результати говорять, що більше половини опитаних схильні до високих рівнів, як ситуативної так особистісної тривожності, а це говорить про постійне хвилювання, невпевненість в собі, недостатнє емоційне пристосування до тих чи інших соціальних ситуацій.

Внаслідок цих проявів розвиваються : непродуктивні форми реагування; симптоми порушення поведінки; емоційні розлади різного ступеня.

Дослідження адаптаційного періоду також передбачає вивчення провідного навчального мотиву. Мотивація студента один з найважливіших пунктів в процесі навчання. Правильна мотивація є правильним фундаментом у навчанні,є базою для подальшого розвитку у професійній сфері.

Існують різні групи мотивів: 
суспільстві);

соціальні (прагнення особистості через навчання створити свій соціальний статус у

спонукальні, які пов'язані з впливом на свідомість тих, хто навчається, певних чинників - вимог батьків, порад, прикладів викладачів, різних членів колективу);

пізнавальні, що виявляються в пробудженні пізнавальних інтересів і реалізуються через отримання задоволення від самого процесу пізнання і його результатів;

професійно-ціннісні, які відображають прагнення студентів отримати грунтовну професійну підготовку для ефективної діяльності в різних сферах життя.

У формуванні студента як суб’єкта навчання позитивну роль відіграють саме навчально-пізнавальні мотиви, які спонукають його до навчальної діяльності.

Для вивчення змісту мотивів до навчання у студентів першого курсу доцільно використати методику вивчення мотивації Т. І. Ільїної, яка включає три шкали: «Набуття знань» (прагнення до набуття знань, допитливість); «Оволодіння професією» (прагнення оволодіти професійними знаннями та сформувати професійно важливі якості); «Отримання диплома» (прагнення отримати диплом при формальному засвоєнні знань, прагнення до пошуку обхідних шляхів при складанні іспитів та заліків).

Аналіз отриманих даних за методикою Т. І. Ільїної показує, що 63\% студентів мають високий та вище середнього мотив набуття знань, тоді як низький рівень мають $30 \%$ студентів, мотив оволодіння професією, формування важливих професійних знань присутній у 40\% студентів (високий рівень та вище середнього). 37\% студентів першого курсу не стурбовані намірами оволодіти професійними навичками. Це може бути пов'язане з тим, що студенти-першокурсники не чітко уявляють зміст майбутньої професійної діяльності. Отримати диплом при формальному засвоєнні знань мають намір 52\% студентів (високий та вище середнього). Для більш глибинного вивчення особистості студента, у разі виявлення критичних показників за попередніми методиками, доцільно проведення індивідуальних діагностичних обстежень таких сфер: вивчення самооцінки схильності до депресивних тенденцій (Шкала самооцінки); дослідження поведінкової сфери (Методика виявлення схильності до неадекватної поведінки; Методика диференційної діагностики депресивних станів авт. В.Зунг, адапт. Т. І. Балашової; Шкала депресії Е. Бека).

Консультативно-просвітницька діяльність. Результати роботи психолога на другому етапі повинні стати основою для формування узагальненої картини щодо перебігу процесу адаптації новоприбулих студентів. Окрім того, визначається коло осіб, які потребують особливої уваги з боку як викладацького складу, так і психолога (рівень «дезадаптація» і «стійка дезадаптація»), та які перебувають у «зоні ризику» (рівень «переддезадаптація»). Із такими студентами планується корекційно-розвивальна робота, яка може здійснюватись у вигляді групової корекційно-розвивальної роботи, індивідуальної корекційної роботи зі студентами «групи ризику».

Підсумково-оцінювальна робота передбачає оцінку результативності консультативно-просвітницької, корекційно-розвивальної роботи проведеної психологом.

Спостереження та дослідження процесу адаптації студентів груп нового набору на базі Сарненського педагогічного коледжу РДГУ, дозволяють виділити наступні головні труднощі:

- переживання, пов’язані з перехідним періодом: від шкільного до дорослого життя; невизначеність мотивації вибору професії;

- недостатня психологічна підготовка до самостійного життя, необхідності приймати рішення, брати на себе відповідальність за власні дії та вчинки;

- пошук оптимального режиму праці і відпочинку в нових умовах;

- налагодження побуту і самообслуговування, особливо при переході до життя у гуртожитку;

- неготовність до сприйняття великого обсягу навчального матеріалу та опрацювання великої кількості інформації;

- відсутність навичок самостійної роботи; 
- невміння будувати міжособистісні стосунки у студентському колективі, бути толерантними та терпимими до недоліків інших (при спільному проживанні у кімнаті гуртожитку) тощо.

Усі ці труднощі різні за своїм походженням. Деякі з них є об'єктивно неминучі, інші носять суб'єктивний характер і пов'язані зі слабкою підготовкою, прогалинами виховання у родині та школі.

Спираючись на результати роботи практичних психологів можна виділити наступні симптоми психологічної дезадаптації у студентів:

- підвищення показника емоційного збудження, тривожності.

- зниження комунікабельності, емоційної стійкості, самоконтролю, соціальної сміливості;

- з'являється почуття неповноцінності у стосунках із товаришами, викладачами, батьками, а в поведінці в цілому - надмірна сором'язливість;

- зниження успішності, недостатня увага й зосередженість на заняттях;

- скарги на погане самопочуття, сон.

Висновки 3 даного дослідження і перспективи подальших розвідок. Провівши теоретичні та практичні дослідження можна зробити висновок, що процес адаптації студента-першокурсника до умов навчання у вищому навчальному закладі - це прийняття норм нового соціального середовища, внутрішне та зовнішне ставлення до цих норм та включення до системи міжособистісних стосунків у групі. Грамотно складена програма соціально-психологічного супроводу студента у період адаптації до навчання у вузі сприятиме зменшенню труднощів навчально-пізнавальної діяльності студентів (труднощі становлення самооцінки, формування позитивного образу «Я»); подоланню дезадаптаційних проявів у поведінковій та емоційній сфері студентів; формуванню сприятливого психологічного клімату в студентському середовищі; залученню студентів до позанавчальної діяльності як передумови успішної адаптації у вузі; створенню сприятливого освітнього середовища $з$ метою адаптації студентів до майбутньої професії (засвоєння професійних компетенцій; формування необхідних якостей).

\section{Список використаних джерел}

1. Авдєєва I. М. Інноваційні комунікативні технології в роботі куратора академгрупи : навч. посіб. / І. М. Авдєєва, І. М. Мельникова. - Київ : ВД «Професіонал», 2007. - 304 с.

2. Буяльська Т. Б. Теоретичні та практичні аспекти роботи кураторів 3 адаптації студентів першого курсу в умовах вищого навчального закладу / Т. Б. Буяльська, М. Д. Прищак // Вісник Вінницького політехнічного інституту. - 2008. - № 5. - С. 105-112.

3. Дубасенюк О. А. Методичні рекомендації куратору академічної групи з виховної роботи серед студентів педуніверситету / О. А. Дубасенюк. - Житомир : Житомир. держ. пед. ун-т, 2000. -87 с.

4. Дябел Л. І. Методичні рекомендації для занять по соціалізації студентівпершокурсників / Л. І. Дябел. - Київ : НПУ імені М. П. Драгоманова, 2005. - 33 с.

5. Методичні рекомендації до планування виховної роботи з студентами у вищих навчальних закладах освіти III - IV акредитації // Інформ. зб. Міносвіти України. - 1998. № $17-18 .-$ С. $50-53$.

6. Методичний посібник куратора академічної групи (основні нормативно-правові та організаційно-методичні матеріали куратора академічної групи) / уклад. : Є. П. Масюткін, I. М. Грицаєнко. - Мелітополь : Тавр. держ. агротехн. акад., 2001. - 81 с.

7. Большой психологический словарь / под ред. : Б. Р. Мещерякова. - М., 2003. $672 \mathrm{c}$.

\section{References}

1. Avdjejeva I. M. Innovacijni komunikatyvni tehnologii' v roboti kuratora akademgrupy : navch. posib. / I. M. Avdjejeva, I. M. Mel'nykova. - Kyiv : VD «Profesional», 2007. - 304 s. 
2. Bujal's'ka T. B. Teoretychni ta praktychni aspekty roboty kuratoriv $\mathrm{z}$ adaptacii' studentiv pershogo kursu v umovah vyshhogo navchal'nogo zakladu / T. B. Bujal's'ka, M. D. Pryshhak // Visnyk Vinnyc'kogo politehnichnogo instytutu. - 2008. - № 5. - S. 105-112.

3. Dubasenjuk O. A. Metodychni rekomendacii' kuratoru akademichnoi' grupy z vyhovnoi' roboty sered studentiv peduniversytetu / O. A. Dubasenjuk. - Zhytomyr : Zhytomyr. derzh. ped. unt, 2000. $-87 \mathrm{~s}$.

4. Djabel L. I. Metodychni rekomendacii' dlja zanjat' po socializacii' studentivpershokursnykiv / L. I. Djabel. - Kyiv : NPU imeni M. P. Dragomanova, 2005. - 33 s.

5. Metodychni rekomendacii' do planuvannja vyhovnoi' roboty z studentamy u vyshhyh navchal'nyh zakladah osvity III - IV akredytacii' // Inform. zb. Minosvity Ukrai'ny. - 1998. № 17-18. - S. 50-53.

6. Metodychnyj posibnyk kuratora akademichnoi' grupy (osnovni normatyvno-pravovi ta organizacijno-metodychni materialy kuratora akademichnoi' grupy) / uklad.: Je. P. Masjutkin, I. M. Grycajenko. - Melitopol' : Tavr. derzh. agrotehn. akad., 2001. - 81 s.

7. Velykyj psyhologichnyj slovnyk / pid red. : B. R. Meshherjakova. - M., 2003. - 672 s.

\section{Shchedrina M.M. SOCIAL PSYCHOLOGICAL SUPPORT OF THE STUDENT DURING THE PERIOD OF THE ADDAPTATION TO THE STUDIES IN THE HIGHER ESTABLISHMENT.}

Personal professional development of the future specialist begins at the higher establishment, where his important professional qualities, interests, needs, creative abilities are formed and general level of culture is being developed.

The theoretical analyses of the existing approaches to the students adaptation studies problems in the higher institutions is shown in the article. The main problems of adaptation of students to higher education are revealed. The results of the survey of the freshmen are presented and a proposal for improving the adaptation process of the freshmen to the studies in the higher establishment is given.

\section{ОСОБЛИВОСТІ РОЗВИТКУ ЗМІСТОВНИХ КОМПОНЕНТІВ ВІЗУАЛЬНОГО МИСЛЕННЯ ПІДЛІТКІВ}

В статті проаналізовано змістовні компоненти візуального мислення підлітків иляхом використання методики Фідлера. Виділено особливості візуального мислення підлітків, як однієї з складових загальної інтелектуальної діяльності. Науково обтрунтовано специфіку розвитку змістовних компонентів візуального мислення підлітків.

Ключові слова: змістовні компоненти візуального мислення, методика Фідлера, (піктограма) підлітковий вік, візуалізація.

В статье диагностированы содержательные компоненты визуального мышления подростков путем использования методики Фидлера. Выделено особенности визуального мышления подростков, как одной из составляющих общей интеллектуальной деятельности. Научно обосновано специфику развития содержательных компонентов визуального мыишления подростков.

Ключевые слова: содержательные компоненты визуального мышления, методика Фидлера (пиктограмма), подростковый возраст, визуализаџия.

Постановка проблеми. Візуальне мислення $\epsilon$ одним 3 основних видів інтелектуальної діяльності в підлітковому віці і характеризується певними процесуальними особливостями (здатністю до висування репродуктивних та оригінальних візуальних гіпотез, конструктивною активністю та категоріальною гнучкістю) та наявністю специфічних 